\title{
Review \\ The value of animal models in predicting genetic susceptibility to complex diseases such as rheumatoid arthritis
}

\author{
Emma Ahlqvist ${ }^{1, *}$, Malin Hultqvist ${ }^{1, *}$ and Rikard Holmdahl ${ }^{1,2}$
}

\author{
${ }^{1}$ Medical Inflammation Research, Lund University, C12 BMC, 22184 Lund, Sweden \\ ${ }^{2}$ Medical Inflammation Research, Department of Medical Biochemistry and Biophysics, Karolinska Institutet, Scheeles väg 2, 17177 Stockholm, \\ Sweden \\ *These authors contributed equally to this work
}

Corresponding author: Rikard Holmdahl, rikard.holmdahl@ki.se

Published: 19 May 2009

This article is online at http://arthritis-research.com/content/11/3/226

(C) 2009 BioMed Central Ltd

\begin{abstract}
For a long time, genetic studies of complex diseases were most successfully conducted in animal models. However, the field of genetics is now rapidly evolving, and human genetics has also started to produce strong candidate genes for complex diseases. This raises the question of how to continue gene-finding attempts in animals and how to use animal models to enhance our understanding of gene function. In this review we summarize the uses and advantages of animal studies in identification of disease susceptibility genes, focusing on rheumatoid arthritis. We are convinced that animal genetics will remain a valuable tool for the identification and investigation of pathways that lead to disease, well into the future.
\end{abstract}

\section{Introduction}

The history of genome-wide mapping of disease-causing genes began in 1980, when linkage analysis by use of anonymous genetic markers was suggested as a method for conducting 'forward genetics' analyses (hypothesis-free mapping starting from a trait of interest) [1]. This soon led to successful identification of several disease-causing genes, often providing the first information on disease mechanisms.

In principal, there are two approaches to genetic mapping: linkage and association analysis (reviewed in [2]). Linkage analysis is based on inheritance of chromosomal fragments within families with affected and unaffected individuals. It allows genome-wide mapping with limited resources, but it can generally only map loci into large genomic regions that span hundreds of genes and, despite great success in monogenic diseases, linkage analysis seems to be of limited use in mapping of complex traits. Association studies compare large unrelated groups of patients with the healthy population to find regions that are overrepresented in patients. This increases mapping precision dramatically but it requires large repositories of patient materials and very closely spaced genetic markers, creating a need for correction for multiple testing, which raises the threshold for claiming statistical significance. Until recently, candidate gene studies were the only realistic way to utilize patient materials for association studies. The major disadvantage of candidate studies is the need for a starting hypothesis to choose candidates. The most interesting prospect of gene mapping, however, is that hypothesis-free mapping can point to previously unknown and unexpected disease pathways.

Neither of these strategies has been successful in mapping genes that control complex diseases, such as rheumatoid arthritis (RA), in humans. Mapping in animal models therefore emerged as an attractive alternative. Choosing candidates identified by positional cloning in animal models combines the high power of candidate studies with the benefits of hypothesis-free mapping.

The traditional strategy to map genes in animals is to intercross two inbred strains that differ in the trait of interest for at least two generations, thereby allowing chromosome regions to segregate, and permitting linkage analysis in a setting with minimal genetic and environmental variation (Figure 1). Not only is the mapping power superior to that in human linkage analysis, but also the identified loci can be isolated on a fixed genetic background to confirm the position of the locus by backcrossing to one of the parental strains for several generations to create a congenic strain (an inbred strain with only a defined genetic region originating from

$\mathrm{CAIA}=$ collagen antibody-induced arthritis; $\mathrm{ClA}=$ collagen-induced arthritis; $\mathrm{Cll}=$ collagen type II; GWA = genome-wide association; IL = interleukin; $\mathrm{MHC}=$ major histocompatibility complex; $\mathrm{MHCll}=\mathrm{MHC}$ class II molecules; $\mathrm{NADPH}=$ nicotinamide adenine dinucleotide phosphate; PGIA = proteoglycan (aggrecan)-induced arthritis; PIA = pristane-induced arthritis; $\mathrm{QTL}=$ quantitative trait locus; $\mathrm{RA}=$ rheumatoid arthritis; ROS = reactive oxygen species. 
Forward genetics/Hypothesis free mapping

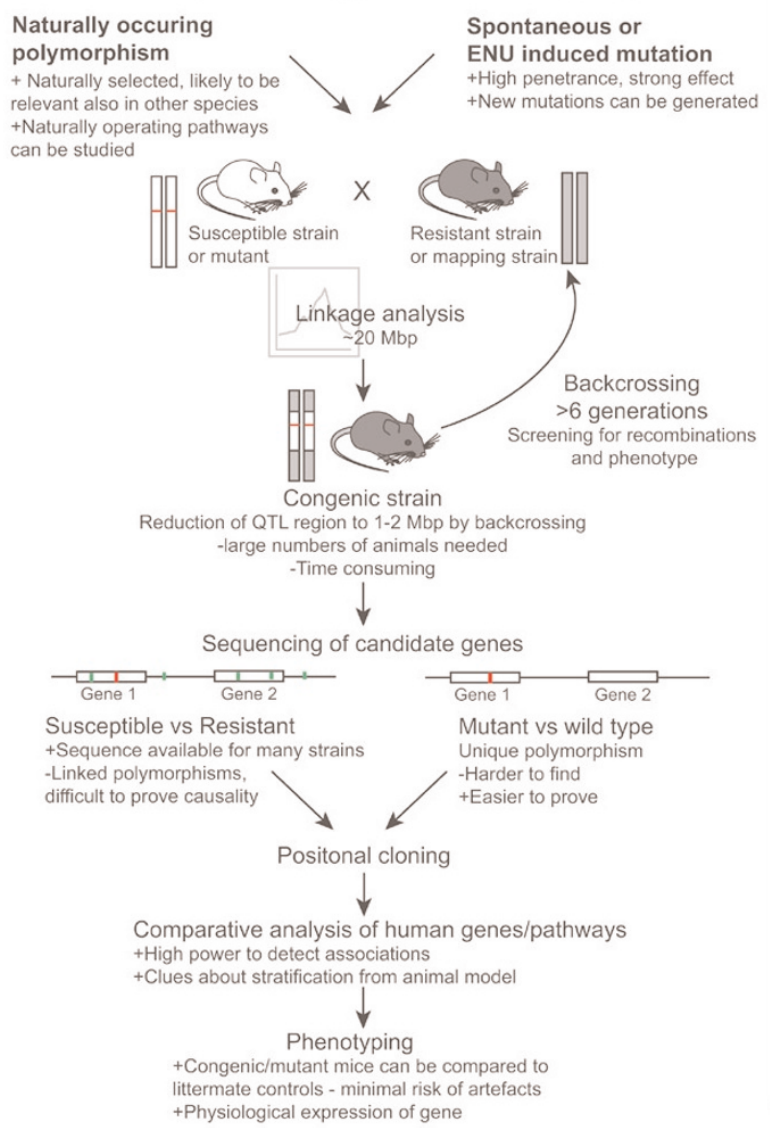

Reverse genetics/Confirmation studies

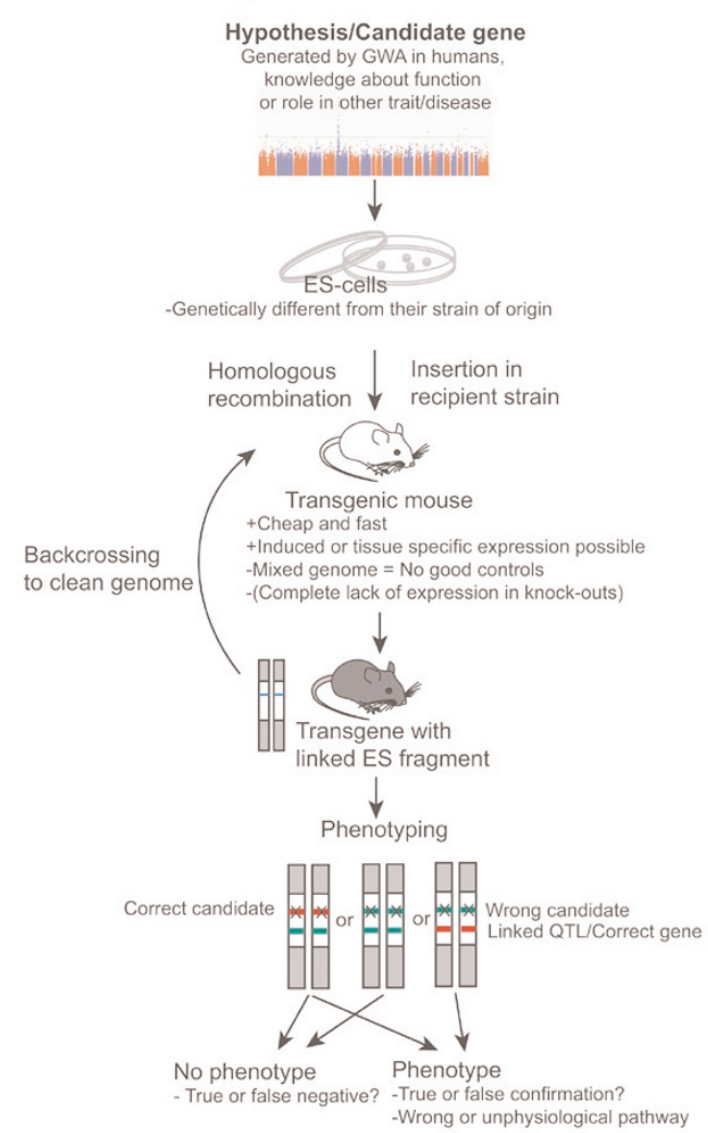

Strategies in animal models. Presented are the most common strategies employed to identify and validate a candidate gene using animal models. GWA, genome-wide association; QTL, quantitative trait locus.

another strain). The congenic region can then be minimized by further backcrossing, checking each generation to make sure that the quantitative trait locus (OTL) is still within the congenic fragment, until only the causative gene remains.

As in the tale of the tortoise and the hare, human genetics has been regarded as fast but unreliable, whereas animal genetics is slow and laborious but likely to find the gene sooner or later. However, even though a few victories have been won by the tortoise, thanks to denser genotyping and considerably larger patient cohorts that allow near genome-wide association (GWA) mapping, human genetics has also started to produce strong candidate genes for complex diseases. In light of this success, we must consider how best to use animal models in the future; is there still value in identifying the genes that affect susceptibility to disease in these species as well?

Clearly, major challenges remain in human genetics that can be resolved in animals. Most genes with medium or small effects still need the focused and strategic work of animal geneticists to reveal their secrets, and only animal genetics studies allow controlled, repeated experiments that can determine causality without doubt. Most important, however, is that although human genetics often faces dead ends because the function of the identified gene is unknown, animal models allow us to investigate the role played by the genes and to perform conclusive experiments to investigate disease mechanisms and develop more precise treatments.

\section{Current status of human genetics research}

The advent of GWA in humans ushered in a new era in disease genetics. GWA studies have been very successful in identifying with statistical rigour the genes that are responsible for several complex diseases, including arthritis, which is reviewed in detail in other articles in this series (for another review, also see [3]). However, at this stage the human GWA studies still wrestle with severe problems and limitations; this is particularly apparent in arthritis studies, where success has been more moderate than for many other complex diseases. 
The major problem is the strict correction for multiple testing needed to exclude false positives after performing hundreds of thousands, or even millions, of tests. It is therefore estimated that materials from tens of thousands of patients and control individuals are needed to identify the majority of genetic effects [4]. Studies combined with retesting in other materials is likely to allow confirmation of the strongest of these associations in the near future, but most are likely to elude mapping. This will be especially true for diseases such as RA, for which studies thus far suggest that the patient population must be stratified into smaller patient groups, resulting in smaller bodies of patient materials and even larger numbers of tests $[5,6]$. This problem will be even worse if interactions are to be addressed. This is an important issue because it is likely that much of the genetic influence is through patterns of interacting genes.

Another issue is the limited possibilities for follow-up experiments in humans. Many loci found by association mapping are located in intergenic regions, including two of the strongest loci for RA, namely TRAF1-C5 and TNFAIP3OLIG3, making it difficult to establish causality $[7,8]$. TRAF1 and TNFAIP3 have been favoured as candidates based on previous knowledge of their function in tumour necrosis factor signalling $[9,10]$, which is known to be important in RA (reviewed in [11]). Although it is likely that these genes truly are involved in the pathogenesis of RA, this remains to be proven; as for candidate studies, this type of reasoning is counter to one of the main aims: hypothesis-free generation of new knowledge. Interestingly, C5 has already been implicated, based on studies conducted in mice [12-14], and it should therefore be considered an equally likely candidate. Similar problems have been apparent for half a century in elucidating the major histocompatibility complex $(\mathrm{MHC})$ region, in which the genes may operate as linked units, haplotypes. More precise phenotypic information and biological knowledge is needed to understand these genetic regions.

\section{Animal models and their relevance to rheumatoid arthritis}

The value of mapping in animals is dependent on there being good models of human diseases. In this review we focus on RA, a highly heterogeneous autoimmune disease that is known to depend on multiple genes and environmental factors. The disease models should therefore preferably be correspondingly polygenic and dependent on environment. There are a number of available animal models for RA that all mimic various aspects of the disease, possibly reflecting disease pathways that operate in different subgroups of RA patients. Thus, all of these models can be valuable under certain conditions, depending on the question that is to be addressed.

\section{Induced arthritis models}

If an antigen is known to induce disease, then this permits studies of the antigen-specific response and allows mapping of the genes involved. Collagen-induced arthritis $(\mathrm{CIA})$ is induced by the major collagen found in cartilage, namely collagen type II (CII), emulsified in adjuvant $[15,16]$. Disease develops 2 to 3 weeks after immunization in susceptible strains $\left(\mathrm{H}-2^{q}\right.$ or $\left.\mathrm{H}-2^{r}\right)$ [17]. CIA is the most widely used model for studying arthritis pathology and for testing for novel antiinflammatory therapeutics [18].

Proteoglycan (aggrecan)-induced arthritis (PGIA), characterized by a progressive disease course, is induced by cartilage proteoglycans. PGIA presents with $100 \%$ incidence in BALB/c mice $\left(H-2^{d}\right)$, which are normally resistant to CIA [19], and manifest in substrains of $\mathrm{C} 3 \mathrm{H}\left(\mathrm{H}-2^{\mathrm{k}}\right)$ [20]. CIA and PGIA are the two most commonly used RA models for QTL mapping in mice. Both models are complex highly polygenic diseases that are dependent on both B and T cells [21-24] and are both associated with $\mathrm{MHC}$ class II molecules (MHCll) and a large number of both common and unique non-MHC loci (Figure 2) [17,25]. Both CIA and PGIA are believed to have relevance to human disease because antibodies to both $\mathrm{Cll}$ and proteoglycan in RA patients have been identified [26-28].

Other cartilage structures that can induce arthritis include cartilage oligomeric matrix protein $[29,30]$ and type XI collagen [31].

Collagen antibody-induced arthritis (CAIA) is induced by injection of specific monoclonal Cll antibodies [32]. The model was developed based on the finding that serum from arthritic mice or RA patients could transfer arthritis to naïve mice $[33,34]$. CAIA resembles CIA but is more acute and has a rapid onset, a few days after injection. Normally, the disease heals after a month and mice remain healthy. The CAIA model is unique because it is independent of $\mathrm{MHC}$ and $\mathrm{T}$ and $\mathrm{B}$ cells $[35,36]$. Instead, neutrophils and macrophages are recruited and activated independent of the adaptive immune system, as a result of antibodies binding to the cartilage surface and fixing complement [36]. This allows investigation of effector mechanisms without involvement of the priming phase.

A number of bacteria also have the capacity to induce arthritis in animals. Mice infected with Borrelia develop a disease similar to RA (B. burgdorferi associated arthritis) [37] and Staphyolococcus aureus causes septic arthritis in both rats and mice $[38,39]$. Bacterial components, such as cell wall fragments, DNA and heat shock proteins, can also induce arthritis by themselves, one example being the streptococcal cell wall induced arthritis model [40]. In rats, exposure to heat-killed Mycobacterium tuberculosis in adjuvant results in Mycobacterium induced-arthritis, often referred to as adjuvant-induced arthritis [41]. This model was developed in 1947 when it was found that a mixture of mineral oils, emulsifier and mycobacteria - namely complete Freund's adjuvant - was a potent immunological adjuvant. It was later found that a similar mixture but excluding myco- 
Figure 2

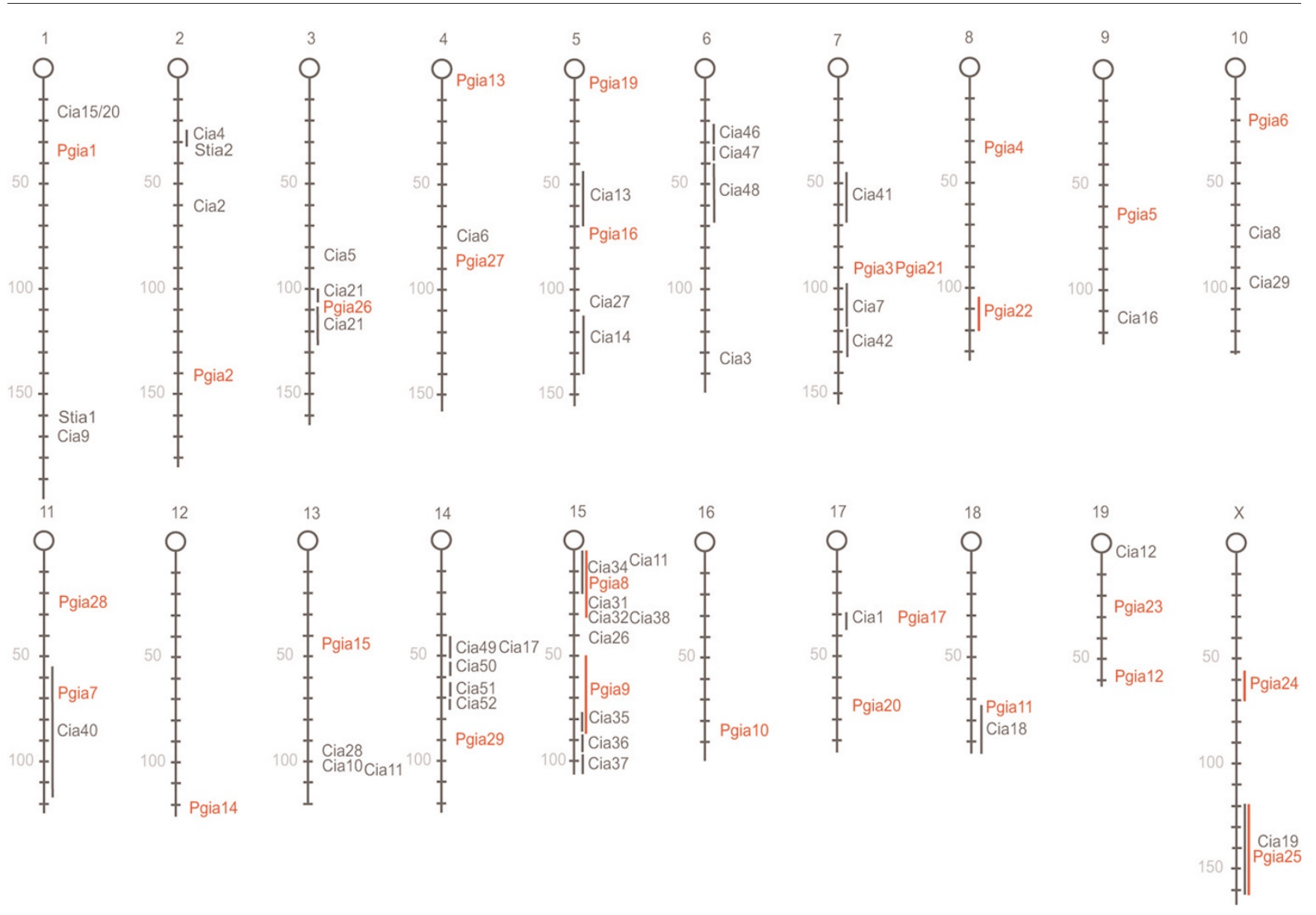

Overview of CIA, PGIA and STIA loci mapped in mouse. CIA, collagen-induced arthritis; PGIA, proteoglycan (aggrecan)-induced arthritis; STIA, serum transfer-induced arthritis.

bacteria (incomplete Freund's adjuvant) also had arthritogenic capacity (oil-induced arthritis) [42]. In addition, some mineral oils by themselves had the capacity to induce arthritis, including squalene [43] and pristane [44].

Pristane-induced arthritis (PIA) in rats highly resembles many aspects of the human disease because it is chronic, symmetrical, and serum rheumatoid factor is present and radiographic changes are apparent $[44,45]$. Even though pristane does not contain peptides that could bind to MHC, PIA has been shown to be T-cell driven and dependent on $\mathrm{MHCll}$ [46], suggesting that the arthritogenic $\mathrm{T}$ cells recognize a self-antigen on the MHC complex, but thus far no such antigen has been identified.

\section{Genetically altered mice as models of arthritis}

There are also animal models that are produced using transgenic techniques, and develop arthritis spontaneously, which can be used to map modifier genes. Examples are IL-1 receptor antagonist knockouts, IL-1 over-expressing mice, gp130 knock-ins and human tumour necrosis factor- $\alpha$ transgenic mice [47-50]. $\mathrm{K} / \mathrm{B} \times \mathrm{N}$ mice express a transgenic $\mathrm{T}$-cell receptor (KRN) and the $\mathrm{NOD}$-derived $\mathrm{Ag}^{7} \mathrm{MHCll}$ allele, and develop severe arthritis spontaneously [51]. The autoantigen is the ubiquitously expressed enzyme glucose-6-phosphate isomerase [52], but inflammation is restricted to the joints, and the disease exhibits many of the characteristics of human RA. Autoantibodies play a pathogenic role in this model, because arthritis can be transferred to a wide range of recipients with serum from $\mathrm{K} / \mathrm{B} \times \mathrm{N}$ mice (serum transferinduced arthritis) [53]. Arthritis can also be induced by injection of recombinant glucose-6-phosphate isomerase in mice [54].

In addition, there are spontaneous models that develop arthritis because of a single mutation. These models can be derived as a result of a spontaneous mutation or following $N$ ethyl- $N$-nitrosurea mutagenesis. The causative mutation can then be positionally cloned by means of linkage analysis (Figure 1). 


\section{Genetic modifications of animals}

With emerging knowledge of the major genes that underlie human disease and improved animal models, it seems straightforward to investigate the in vivo function of these genes in the animal models. To this end, the particular genes can be humanized or modified in mice and the effect of the specific mutations on disease development investigated (Figure 1). Of particular use will be new technologies to modify the genome, which will allow researchers to introduce genes, mutate genes in specific tissues and express proteins flagged with various markers. There are, however, some significant drawbacks that have thus far limited the use of this technology, and these need to be highlighted. First, it is essential that the modifications are dependent on the genetic context (the new genetic modifications will interact with other genes in the genome, specifically mouse genes). Second, to conduct conclusive experiments and compare them between different laboratories, the genetic background must be inbred and standardized. Finally, modifications to the genome lead to artifacts that interfere with interpretation of the results. Clearly, to use genetic modifiactions we must obtain better knowledge about the genomic control of the disease in question in mice. We first discuss some of the problems that genetic modifications may cause.

Although transgenic or genetic knockout strategies are appealing, being relatively fast and cost efficient, it is important to appreciate that they carry a high risk of artifacts. Despite the efficiency of inserting a mutation that completely disrupts the function of a gene, most genetic factors in common complex diseases are expected to be noncrucial, coding single nucleotide polymorphisms or expression differences [55]. Complete elimination of a gene does not necessarily have the same effect as a smaller change that affects, for instance, expression kinetics or binding to a target molecule. Accordingly, studies of knockout mice have identified phenotypes that are fundamentally different from what was expected from the naturally occurring locus. This is clearly seen in the case of the Ncf1 gene. Mice with a spontaneous mutation in this gene, resulting in a truncated protein, exhibit increased susceptibility to models of arthritis and even develop arthritis spontaneously [56], whereas knockout of Ncf1 results in chronic granulomatous disease with severe infections as a consequence [57]. The same problems apply to other types of transgenes in which a construct is expressed outside its normal context, possibly with dramatic effects on gene regulation and protein expression. This can also be true in humanized mice, in which human genetic variants have been introduced in an artificial genetic interactive environment. Nevertheless, these mice can be extremely useful in clarifying specific questions. For example, humanized mice have successfully been used to investigate the individual roles of $\mathrm{MHC}$ class II molecules (MHCII) in arthritis and were proven to be useful in identifying T-cell epitopes (reviewed in [58]).
Another important issue when studying polygenic diseases is that transgenics can normally not be made directly in the strain that will be used for experiments. Transgenic mice are instead made in embryonic stem cells, usually from the 129 or C57BL/6 strains, and backcrossed to the strain of interest, thus creating a mixed genome with a 129 or $\mathrm{C} 57 \mathrm{BL} / 6$ region surrounding the insert. Even after 10 generations of backcrossing, there is almost $40 \%$ risk that a locus $10 \mathrm{cM}$ from the targeted gene is still within this fragment, a region that could contain hundreds of genes [59]. Based on findings from mappings of CIA in mouse, it is quite likely that this congenic fragment will contain QTLs that affect the trait, making it impossible to know whether the phenotype truly originates from the transgene (Figure 2) [60-62].

Such linked QTLs have proven to be a problem in several studies. For example, the osteopontin (Opn) gene was suggested to be involved in autoimmunity based on phenotyping of a knockout strain, but it was later revealed that another Opn knockout had no such phenotype, and that the effect was probably due to liked genes in the 129 fragment [63]. More recently, contradictory data about the role of IL-21 in autoimmunity and differentiation of T-helper-17 cells have led to a similar discussion. In fact, none of the studies using IL-21 or IL-21 receptor knockout mice were set up such that the influence of other genes could be excluded [64]. This is especially problematic if the aim is to confirm the mapping of a candidate gene. Random insertion may affect the usage of the gene whereas targeted insertion will place it within a congenic region that might contain the QTL studied, yielding false-positive confirmation (Figure 1). Most importantly, there is a risk that only hypothesisconfirming results will be reported, without any correction for multiple testing.

\section{Gene findings in animal models}

Linkage analysis of segregating crosses between inbred strains with different susceptibilities to arthritis has proven to be very efficient and informative. It has confirmed polygenicity and shown that some, but not all, loci are shared between models and strain combinations. Figure 2 shows loci controlling CIA (40 loci) and PGIA (29 loci) in mice [65]. The majority of these loci were mapped in genome-wide $\mathrm{F}_{2}$ crosses. However, parts of chromosomes $3,6,7,14$ and 15 have been fine mapped in partial advanced intercrosses and subcongenic strains, and in all regions studied loci have appeared where nothing was detectable in $\mathrm{F}_{2}$ crosses, suggesting that the locus density could be as high on all chromosomes [60-62,66]. Similar numbers of loci have been mapped in rat models of arthritis: 29 for CIA, 39 for PIA, eight for oil-induced arthritis and five controlling adjuvant-induced arthritis [67]. These finemapping studies suggest that multiple arthritis loci on a chromosome is the rule rather than the exception; it is especially important to bear this in mind when designing experiments in genetically modified strains. 
Another important accomplishment of animal genetics is the study of gene-gene interactions. Studying interactions is statistically challenging because of the enormous number of tests that must be conducted. Animal crosses allow mapping and modelling of multiple locus interactions, which has turned out to be of fundamental importance in some phenotypes. The Cia21 and Cia22 loci increase susceptibility to arthritis in mice only in the presence of RIIIS/J alleles in the Cia32 locus, which also interacts with Cia31 and Cia26 [61]. Including interactions in the analysis has also allowed mapping of several other loci, including Cia41 and Cia42 in mouse and Cia26 in rats $[60,68]$. Performing this type of study in humans would require even larger patient populations and computation resources, and will remain unfeasible for many years yet.

Positioning of the underlying genes has, as expected, not been achieved with similar ease. Initial expectations of rapid gene identification have been based on an underestimation of the complexity of the disease, even if it is bound to be less extensive than in the human situation. Another problem has been to find relevant recombinations that split the strongly linked genetic fragments controlling disease. The genetic effect may in fact be dependent on haplotypes rather than on single genetic polymorphisms. In spite of this, a number of genes - for example, MHC/l [17,69,70], Ncf1 [56,71] and Hc (C5) [12-14] - have been successfully identified as arthritis regulating using animal models. Furthermore, the Oia2 locus in rats has been shown to be caused by variation in a gene complex encoding C-type lectin-like receptors ( $A P L E C)$, but thus far it has not been possible to establish which of the genes is responsible for the effect [72].

The $\mathrm{MHC} / \mathrm{l}$ region was the first locus found to be associated with arthritis in both mice [17,69] and humans [73], and it remains the strongest association in both species. It was recognized early on that CIA susceptibility was almost exclusively seen in inbred strains that had either $\mathrm{H}_{2}^{\mathrm{q}}$ or $\mathrm{H}^{\mathrm{r}}$ haplotype at the $\mathrm{MHC}$ locus $[17,69]$. The $\mathrm{H}^{\mathrm{p}}$ protein, which renders mice nonsusceptible to $\mathrm{CIA}$, differs from $\mathrm{H}_{2}{ }^{q}$ only by four amino acids in the peptide binding groove, and changing these to the corresponding amino acids in the $\mathrm{H}^{\mathrm{q}} \mathrm{q}$ sequence makes the $\mathrm{H}^{p}$ mice susceptible to $\mathrm{ClA}$ [70]. Interestingly, the binding groove of the $\mathrm{H}^{2} \mathrm{q} \mathrm{MHC}$ strongly resembles that of the human $H L A-D R B 1^{*} 04$ and *01 shared epitope haplotypes, which are associated with increased risk for development of RA. Furthermore, transgenic mice expressing the human risk haplotypes are susceptible to CIA [74].

The C5 gene is a very strong candidate gene for the Cia2 locus, which has been identified in two different $F_{2}$ crosses, including the NOD.Q and SWR/J strains [12,13]. It has also been confirmed in an advanced intercross and in congenic lines, although in these situations there is evidence for additional contributing genetic influences closely linked to C5 [14]. These strains are C5 deficient because of frame shift deletion and early termination of translation [75]. The C5 polymorphism is not found in wild mice, however, although it is widespread in inbred strain, possibly because of a bottleneck effect during domestication. The suspected role of $\mathrm{C} 5$ and complement in RA has been confirmed in numerous animal experiments and models (reviewed in [76]). Importance in humans has been suggested by increased complement activity in RA joints compared with joints afflicted with other arthritides [77,78] and was also supported by the TRAF1-C5 association [7].

The Ncf1 gene, which encodes the p47phox protein of the phagocytic NADPH (nicotinamide adenine dinucleotide phosphate) oxidase complex, has been positionally cloned as the major gene underlying the Pia4 locus in rats. Surprisingly, the mutation - resulting in low production of reactive oxygen species (ROS) - rendered the animals more susceptible to severe arthritis [71] as a result of altered oxidation status of arthritogenic $\mathrm{T}$ cells [79]. This finding was reproduced in a mouse strain carrying another spontaneous mutation in Ncf1 and with nearly absent ROS production [56,80]. Based on knowledge from the animal studies, we conducted a candidate association study in a human case-control study of RA. Because NCF1 is more complex in human than in mouse, with pseudogenes and copy number variations [81,82], we limited our study to the other subunits of the NADPH oxidase complex. We hypothesized that single nucleotide polymorphisms in any of the other subunits could cause the same reduction in ROS production and thereby affect disease. Accordingly, we found an association with NCF4 (p40phox) in rheumatoid factor negative men [82]. This proves that although not all genetic findings in animals can be directly translated to humans, we can identify pathways in mice that are likely to operate similarly in humans.

A success story for mapping of spontaneous mutations is the SKG mouse, derived from a BALB/c breeding. The SKG mouse strain develops severe chronic arthritis at around 8 weeks of age, because of a mutation in the ZAP7O gene. The SKG model presents with high titres of rheumatoid factor and anti-Cll autoantibodies, suggesting that it resembles RA both clinically and serologically [83]. ZAP70 is a key signal transduction molecule in $\mathrm{T}$ cells $[83,84]$ and the mutation alters sensitivity to thymic selection, resulting in positive selection of otherwise negatively selected autoimmune cells. Interestingly, even though autoreactive $\mathrm{T}$ cells are present in the periphery, an infectious agent is necessary for disease development [85].

\section{The future of animal genetics}

Like genetics research in humans, that in animals has progressed in recent years. A wealth of resources has been developed as a result of collaborative efforts, including bioinformatics tools, sequence and expression databases, and designer animals (for an extensive review of available resources, see [86]). New mouse resources, such as outbred 
stocks and advanced intercrosses, have been put to use to facilitate QTL mapping, and the first studies have reported breathtaking results on the number of QTLs and interactions between genes and environment $[87,88]$.

Outbred strains have high-density recombinations that can allow mapping to subcentimorgan levels in one generation, by combining the advantages of association mapping with the power of mapping in animal models. One such resource is heterogeneous stocks, in which several founder strains have been intercrossed for numerous generations, resulting in a fine mosaic of founder strain haplotypes $[89,90]$. The known ancestry of the alleles increases mapping power compared with natural populations. Furthermore, compared with crosses of only two strains, heterogeneous stocks mice also have a large number of alleles, making it more probable that a QTL segregates in the cross. A number of genes and loci controlling other complex traits have already been mapped in outbred stocks, and studies on arthritis in both mice and rats are on the way $[87,91,92]$.

Another resource that is under development, the collaborative cross, can make the process even more efficient by minimizing the cost of genotyping. By creating 1,000 recombinant inbred lines from eight founder strains that are first intercrossed to mix the genomes and then inbred, a permanent resource of homozygous mice will be generated that can be carefully genotyped once and then used by research groups all over the world [93]. Production of congenic strains for definite determination of causality will be facilitated by starting from genome tagged or chromosomal substitution strains (inbred strains in which part of or an entire chromosome has been exchanged for that of another inbred strain by the same methods used for making congenics) [94]. Large-scale projects are working at generating transgenic mouse lines for all genes, which can be used in confirmatory studies. Furthermore, the increasing access to sequence information from more and more inbred strains will facilitate the identification of causative polymorphisms and strengthen the power of in silico methods for QTL analysis [86]. Unfortunately, the use of many of these resources is limited by the strict $\mathrm{MHC}$ dependency of most arthritis models.

Another interesting prospect is the use of microarray data, to identify expression QTLs [95]. By considering gene expression levels as a quantitative trait, expression QTLs can be mapped directly in crosses, both to identify candidate genes and to indicate the key pathways affected. Of course, animal models have a huge advantage compared with humans because samples can be taken from any tissue or time point in the disease course.

By combining these new resources, mapping in animals could approach the speed of mapping in humans while retaining the advantages of animal experiments.

\section{Relevance of findings made in animal models}

It is sometimes argued that findings made in animals are not necessarily relevant to human disease. Naturally, there are several major differences between human disease and animal models. However, it is likely that the majority of genes will operate in a similar way in humans as in animals. A gene identified in animals might not be associated with disease in humans (for example, because it is not polymorphic in the human population), but it could still be part of a pathway that operates similarly in both species, as in the case of NCF4. This gene would not have been picked up by conventional association studies, because the effect is weak and the subpopulation small. However, thanks to the identification of Ncf1 as a disease-regulating gene in rats and mice, we were able to investigate a completely novel pathway in humans.

Even in the odd case in which the animal model operates through completely different pathways than the human disease, important information is gained, because animal models are central to the development and testing of new therapeutic strategies, and a discrepancy in disease mechanics can lead to catastrophic consequences if the therapy is transferred to the human situation after being proven safe and efficient in animals. This was seen when an anti-CD28 monoclonal antibody unexpectedly induced a life-threatening cytokine storm in volunteers when taken to phase I trials, a tragedy that might have been prevented by a better understanding of the immune system of the model organisms [96].

Another difference is the effect of the environment. Animal studies allow environmental factors to be limited to a minimum by fixed living and eating conditions. Furthermore, the inducing environmental factor is unknown in humans, whereas it is defined in animal models. Although this facilitates experimentation and increases power for the mapping, it can also be limiting in that it excludes environmental factors, some of which may be human specific, that can be pivotal in the pathogenesis of human disease. For example, smoking has been shown to play a role in susceptibility to arthritis and to interact with genetic factors [97].

\section{Conclusions}

It is clear that both human and animal genetics have benefits: human genetics in its certain relevance and relatively fast identification procedure; and animal genetics in its ability to limit complexity and so allow identification of loci with smaller effects, its benefit of allowing conclusive confirmation of findings, and its immense advantage in allowing further investigation and manipulation of the genes and pathways identified. In the same way, transgenic animals and congenic strains have advantages and disadvantages that make them more or less suited for each specific question considered. Attempts to elucidate the tight nest of interacting genetic effects that seem to make up the genetic background of truly complex diseases such as RA will greatly benefit from a joint attack along all avenues of research. 


\section{The Scientific Basis of Rheumatology: years A Decade of Progress}

This article is part of a special collection of reviews, The Scientific Basis of Rheumatology: A Decade of Progress, published to mark Arthritis Research \& Therapy's 10th anniversary.

Other articles in this series can be found at: http://arthritis-research.com/sbr

The different strategies should therefore not be regarded as competing options, but rather as complementary strategies that, together, could provide a true understanding of the genes and pathways that affect human diseases. They may also permit improved understanding of the animal models that we are so dependent on in the development of safe and efficient drugs.

\section{Competing interests}

The authors declare that they have no competing interests.

\section{References}

1. Botstein D, White RL, Skolnick M, Davis RW: Construction of a genetic linkage map in man using restriction fragment length polymorphisms. Am J Hum Genet 1980, 32:314-331.

2. Altshuler D, Daly MJ, Lander ES: Genetic mapping in human disease. Science 2008, 322:881-888.

3. Xavier RJ, Rioux JD: Genome-wide association studies: a new window into immune-mediated diseases. Nat Rev Immunol 2008, 8:631-643.

4. Wang WY, Barratt BJ, Clayton DG, Todd JA: Genome-wide association studies: theoretical and practical concerns. Nat Rev Genet 2005, 6:109-118.

5. van der Helm-van Mil AH, Verpoort KN, Breedveld FC, Huizinga TW, Toes RE, de Vries RR: The HLA-DRB1 shared epitope alleles are primarily a risk factor for anti-cyclic citrullinated peptide antibodies and are not an independent risk factor for development of rheumatoid arthritis. Arthritis Rheum 2006, 54: 1117-1121.

6. Lee AT, Li W, Liew A, Bombardier C, Weisman M, Massarotti EM, Kent J, Wolfe F, Begovich AB, Gregersen PK: The PTPN22 R620W polymorphism associates with RF positive rheumatoid arthritis in a dose-dependent manner but not with HLA-SE status. Genes Immun 2005, 6:129-133.

7. Plenge RM, Seielstad M, Padyukov L, Lee AT, Remmers EF, Ding B, Liew A, Khalili H, Chandrasekaran A, Davies LR, Li W, Tan AK, Bonnard C, Ong RT, Thalamuthu A, Pettersson S, Liu C, Tian C, Chen WV, Carulli JP, Beckman EM, Altshuler D, Alfredsson L, Criswell LA, Amos Cl, Seldin MF, Kastner DL, Klareskog L, Gregersen PK: TRAF1-C5 as a risk locus for rheumatoid arthritisa genomewide study. N Engl J Med 2007, 357:1199-1209.

8. Plenge RM, Cotsapas C, Davies L, Price AL, de Bakker PI, Maller J, Pe'er I, Burtt NP, Blumenstiel B, DeFelice M, Parkin M, Barry R, Winslow W, Healy C, Graham RR, Neale BM, Izmailova E, Roubenoff R, Parker AN, Glass R, Karlson EW, Maher N, Hafler DA, Lee DM, Seldin MF, Remmers EF, Lee AT, Padyukov L, Alfredsson L, Coblyn J, et al:: Two independent alleles at 6 q23 associated with risk of rheumatoid arthritis. Nat Genet 2007, 39:1477-1482.

9. Arron JR, Walsh MC, Choi Y: TRAF-mediated TNFR-family signaling. Curr Protoc Immuno/ 2002, Chapter 11:Unit 11 19D.
10. Opipari AW Jr, Boguski MS, Dixit VM: The A20 cDNA induced by tumor necrosis factor alpha encodes a novel type of zinc finger protein. J Biol Chem 1990, 265:14705-14708.

11. Feldmann M, Maini SR: Role of cytokines in rheumatoid arthritis: an education in pathophysiology and therapeutics. Immunol Rev 2008, 223:7-19.

12. Lindqvist $A K$, Johannesson $M$, Johansson $A C$, Nandakumar $K S$, Blom AM, Holmdahl R: Backcross and partial advanced intercross analysis of nonobese diabetic gene-mediated effects on collagen-induced arthritis reveals an interactive effect by two major loci. J Immunol 2006, 177:3952-3959.

13. Mclndoe RA, Bohlman B, Chi E, Schuster E, Lindhardt M, Hood L: Localization of non-Mhc collagen-induced arthritis susceptibility loci in DBA/1j mice. Proc Natl Acad Sci U S A 1999, 96: 2210-2214.

14. Bauer K, Yu X, Wernhoff $P$, Koczan D, Thiesen HJ, Ibrahim SM: Identification of new quantitative trait loci in mice with collagen-induced arthritis. Arthritis Rheum 2004, 50:3721-3728.

15. Trentham DE, Townes AS, Kang AH: Autoimmunity to type II collagen an experimental model of arthritis. J Exp Med 1977, 146:857-868.

16. Courtenay JS, Dallman MJ, Dayan AD, Martin A, Mosedale B: Immunisation against heterologous type II collagen induces arthritis in mice. Nature 1980, 283:666-668.

17. Wooley PH, Luthra HS, Stuart JM, David CS: Type II collageninduced arthritis in mice. I. Major histocompatibility complex (I region) linkage and antibody correlates. J Exp Med 1981, 154: 688-700.

18. Jirholt J, Lindqvist $A B$, Holmdahl R: The genetics of rheumatoid arthritis and the need for animal models to find and understand the underlying genes. Arthritis Res 2001, 3:87-97.

19. Glant TT, Mikecz K, Arzoumanian A, Poole AR: Proteoglycaninduced arthritis in BALB/c mice. Clinical features and histopathology. Arthritis Rheum 1987, 30:201-212.

20. Glant TT, Bárdos T, Vermes C, Chandrasekaran R, Valdéz JC, Otto JM, Gerard D, Velins S, Lovász G, Zhang J, Mikecz K, Finnegan $A$ : Variations in susceptibility to proteoglycaninduced arthritis and spondylitis among $\mathrm{C} 3 \mathrm{H}$ substrains of mice: evidence of genetically acquired resistance to autoimmune disease. Arthritis Rheum 2001, 44:682-692.

21. Svensson L, Jirholt J, Holmdahl R, Jansson L: B cell-deficient mice do not develop type II collagen-induced arthritis (CIA). Clin Exp Immunol 1998, 111:521-526.

22. Corthay $A$, Johansson $A$, Vestberg M, Holmdahl R: Collageninduced arthritis development requires alpha beta $T$ cells but not gamma delta T cells: studies with T cell-deficient (TCR mutant) mice. Int Immunol 1999, 11:1065-1073.

23. Adarichev VA, Valdez JC, Bardos T, Finnegan A, Mikecz K, Glant TT: Combined autoimmune models of arthritis reveal shared and independent qualitative (binary) and quantitative trait loci. $J$ Immunol 2003, 170:2283-2292.

24. O'Neill SK, Shlomchik MJ, Glant TT, Cao Y, Doodes PD, Finnegan A: Antigen-specific B cells are required as APCs and autoantibody-producing cells for induction of severe autoimmune arthritis. J Immuno/ 2005, 174:3781-3788.

25. Banerjee S, Webber C, Poole AR: The induction of arthritis in mice by the cartilage proteoglycan aggrecan: roles of $\mathrm{CD4}^{+}$ and CD8+ T cells. Cell Immunol 1992, 144:347-357.

26. Cook AD, Gray R, Ramshaw J, Mackay IR, Rowley MJ: Antibodies against the CB10 fragment of type II collagen in rheumatoid arthritis. Arthritis Res Ther 2004, 6:R477-R483.

27. Cook AD, Rowley MJ, Stockman A, Muirden KD, Mackay IR: Specificity of antibodies to type II collagen in early rheumatoid arthritis. J Rheumatol 1994, 21:1186-1191.

28. Glant T, Csongor J, Szucs T: Immunopathologic role of proteoglycan antigens in rheumatoid joint disease. Scand J Immunol 1980, 11:247-252.

29. Carlsen S, Nandakumar KS, Backlund J, Holmberg J, Hultqvist M, Vestberg M, Holmdahl R: Cartilage oligomeric matrix protein induction of chronic arthritis in mice. Arthritis Rheum 2008, 58: 2000-2011.

30. Carlsen S, Hansson AS, Olsson H, Heinegard D, Holmdahl R: Cartilage oligomeric matrix protein (COMP)-induced arthritis in rats. Clin Exp Immunol 1998, 114:477-484.

31. Cremer MA, Griffiths MM, Terato K, Kang AH: Type XI and II collagen-induced arthritis in rats: characterization of inbred strains of rats for arthritis-susceptibility and immune-respon- 
siveness to type XI and II collagen. Autoimmunity 1995, 20: 153-161.

32. Holmdahl R, Rubin K, Klareskog L, Larsson E, Wigzell H: Characterization of the antibody response in mice with type II collagen-induced arthritis, using monoclonal anti-type II collagen antibodies. Arthritis Rheum 1986, 29:400-410.

33. Wooley PH, Luthra HS, Singh SK, Huse AR, Stuart JM, David CS: Passive transfer of arthritis to mice by injection of human anti-type II collagen antibody. Mayo Clin Proc 1984, 59:737743.

34. Stuart JM, Dixon FJ: Serum transfer of collagen-induced arthritis in mice. J Exp Med 1983, 158:378-392.

35. Nandakumar KS, Backlund J, Vestberg M, Holmdahl R: Collagen type II (CII)-specific antibodies induce arthritis in the absence of $\mathrm{T}$ or $\mathrm{B}$ cells but the arthritis progression is enhanced by Cll-reactive T cells. Arthritis Res Ther 2004, 6:R544-R550.

36. Nandakumar KS, Svensson L, Holmdahl R: Collagen type II-specific monoclonal antibody-induced arthritis in mice: description of the disease and the influence of age, sex, and genes. Am J Pathol 2003, 163:1827-1837.

37. Schaible UE, Kramer MD, Wallich R, Tran T, Simon MM: Experimental Borrelia burgdorferi infection in inbred mouse strains: antibody response and association of $\mathrm{H}-2$ genes with resistance and susceptibility to development of arthritis. Eur $J$ Immunol 1991, 21:2397-2405.

38. Bremell T, Lange S, Holmdahl R, Ryden C, Hansson GK, Tarkowski A: Immunopathological features of rat Staphylococcus aureus arthritis. Infect Immun 1994, 62:2334-2344.

39. Bremell T, Lange S, Yacoub A, Ryden C, Tarkowski A: Experimental Staphylococcus aureus arthritis in mice. Infect Immun 1991, 59:2615-2623.

40. Kimpel D, Dayton T, Kannan K, Wolf RE: Streptococcal cell wall arthritis: kinetics of immune cell activation in inflammatory arthritis. Clin Immuno/ 2002, 105:351-362.

41. Pearson CM: Development of arthritis, periarthritis and periostitis in rats given adjuvants. Proc Soc Exp Biol Med 1956, 91: 95-101

42. Kleinau S, Erlandsson H, Holmdahl R, Klareskog L: Adjuvant oils induce arthritis in the DA rat. I. Characterization of the disease and evidence for an immunological involvement. $J$ Autoimmun 1991, 4:871-880.

43. Carlson BC, Jansson AM, Larsson A, Bucht A, Lorentzen JC: The endogenous adjuvant squalene can induce a chronic T-cellmediated arthritis in rats. Am J Patho/ 2000, 156:2057-2065.

44. Vingsbo C, Sahlstrand P, Brun JG, Jonsson R, Saxne T, Holmdahl $R$ : Pristane-induced arthritis in rats: a new model for rheumatoid arthritis with a chronic disease course influenced by both major histocompatibility complex and non-major histocompatibility complex genes. Am J Pathol 1996, 149:1675-1683.

45. Wernhoff $P$, Olofsson $P$, Holmdahl R: The genetic control of rheumatoid factor production in a rat model of rheumatoid arthritis. Arthritis Rheum 2003, 48:3584-3596.

46. Holmberg J, Tuncel J, Yamada H, Lu S, Olofsson P, Holmdahl R: Pristane, a non-antigenic adjuvant, induces MHC class IIrestricted, arthritogenic T cells in the rat. J Immuno/ 2006, 176: $1172-1179$.

47. Keffer J, Probert L, Cazlaris H, Georgopoulos S, Kaslaris E, Kioussis D, Kollias G: Transgenic mice expressing human tumour necrosis factor: a predictive genetic model of arthritis. Embo $J$ 1991, 10:4025-4031.

48. Niki $Y$, Yamada $H$, Seki $S$, Kikuchi $T$, Takaishi $H$, Toyama $Y$, Fujikawa K, Tada N: Macrophage- and neutrophil-dominant arthritis in human IL-1 alpha transgenic mice. J Clin Invest 2001, 107:1127-1135.

49. Horai R, Saijo S, Tanioka H, Nakae S, Sudo K, Okahara A, Ikuse T, Asano M, Iwakura $Y$ : Development of chronic inflammatory arthropathy resembling rheumatoid arthritis in interleukin 1 receptor antagonist-deficient mice. J Exp Med 2000, 191:313320.

50. Atsumi $T$, Ishihara $K$, Kamimura $D$, Ikushima $H$, Ohtani $T$, Hirota $S$, Kobayashi H, Park SJ, Saeki Y, Kitamura Y, Hirano T: A point mutation of Tyr-759 in interleukin 6 family cytokine receptor subunit gp130 causes autoimmune arthritis. J Exp Med 2002, 196:979-990.

51. Kouskoff V, Korganow AS, Duchatelle V, Degott C, Benoist C, Mathis D: Organ-specific disease provoked by systemic autoimmunity. Cell 1996, 87:811-822.
52. Matsumoto I, Staub A, Benoist C, Mathis D: Arthritis provoked by linked $T$ and $B$ cell recognition of a glycolytic enzyme. Science 1999, 286:1732-1735.

53. Korganow AS, Ji H, Mangialaio S, Duchatelle V, Pelanda R, Martin T, Degott C, Kikutani H, Rajewsky K, Pasquali JL, Benoist C, Mathis D: From systemic T cell self-reactivity to organ-specific autoimmune disease via immunoglobulins. Immunity 1999, 10:451-461.

54. Schubert D, Maier B, Morawietz L, Krenn V, Kamradt T: Immunization with glucose-6-phosphate isomerase induces $T$ celldependent peripheral polyarthritis in genetically unaltered mice. J Immuno/ 2004, 172:4503-4509.

55. Thomas PD, Kejariwal A: Coding single-nucleotide polymorphisms associated with complex vs. Mendelian disease: evolutionary evidence for differences in molecular effects. Proc Natl Acad Sci U S A 2004, 101:15398-15403.

56. Hultqvist M, Olofsson P, Holmberg J, Backstrom BT, Tordsson J, Holmdahl R: Enhanced autoimmunity, arthritis, and encephalomyelitis in mice with a reduced oxidative burst due to a mutation in the Ncf1 gene. Proc Natl Acad Sci U S A 2004 101:12646-12651.

57. Jackson SH, Gallin Jl, Holland SM: The p47phox mouse knockout model of chronic granulomatous disease. J Exp Med 1995, 182:751-758.

58. Fugger L, Svejgaard A: Association of MHC and rheumatoid arthritis. HLA-DR4 and rheumatoid arthritis: studies in mice and men. Arthritis Res 2000, 2:208-211.

59. Lusis AJ, Yu J, Wang SS: The problem of passenger genes in transgenic mice. Arterioscler Thromb Vasc Biol 2007, 27:21002103.

60. Ahlqvist E, Bockermann R, Holmdahl R: Fragmentation of two quantitative trait loci controlling collagen-induced arthritis reveals a new set of interacting subloci. J Immunol 2007, 178: 3084-3090.

61. Johannesson $M$, Karlsson J, Wernhoff $P$, Nandakumar KS, Lindqvist AK, Olsson L, Cook AD, Andersson A, Holmdahl R: Identification of epistasis through a partial advanced intercross reveals three arthritis loci within the Cia5 QTL in mice. Genes Immun 2005, 6:175-185.

62. Karlsson J, Johannesson M, Lindvall T, Wernhoff $P$, Holmdahl R, Andersson A: Genetic interactions in Eae2 control collageninduced arthritis and the CD4+/CD8+ T cell ratio. J Immunol 2005, 174:533-541.

63. Blom T, Franzen A, Heinegard D, Holmdahl R: Comment on 'The influence of the proinflammatory cytokine, osteopontin, on autoimmune demyelinating disease'. Science 2003, 299:1845; author reply 1845

64. Holmdahl R: IL-21 and autoimmune disease: hypothesis and reality? Eur J Immuno/ 2008, 38:1800-1802.

65. MGl, www.informatics.jax.org

66. Popovic M, Ahlqvist E, Rockenbauer E, Bockermann R, Holmdahl $\mathrm{R}$ : Identification of new loci controlling collagen-induced arthritis in mouse using a partial advanced intercross and congenic strains. Scand J Immuno/ 2008, 68:405-413.

67. RGD, www.rgd.mcw.edu

68. Meng HC, Griffiths MM, Remmers EF, Kawahito Y, Li W, Neisa R, Cannon GW, Wilder RL, Gulko PS: Identification of two novel female-specific non-major histocompatibility complex loci regulating collagen-induced arthritis severity and chronicity, and evidence of epistasis. Arthritis Rheum 2004, 50:26952705.

69. Holmdahl R, Jansson L, Andersson M, Larsson E: Immunogenetics of type II collagen autoimmunity and susceptibility to collagen arthritis. Immunology 1988, 65:305-310.

70. Brunsberg U, Gustafsson K, Jansson L, Michaelsson E, AhrlundRichter L, Pettersson S, Mattsson R, Holmdahl R: Expression of a transgenic class II Ab gene confers susceptibility to collagen-induced arthritis. Eur J Immunol 1994, 24:1698-1702.

71. Olofsson P, Holmberg J, Tordsson J, Lu S, Akerstrom B, Holmdahl $\mathrm{R}$ : Positional identification of $\mathrm{Ncf} 1$ as a gene that regulates arthritis severity in rats. Nat Genet 2003, 33:25-32.

72. Lorentzen JC, Flornes L, Eklöw C, Bäckdahl L, Ribbhammar U, Guo JP, Smolnikova M, Dissen E, Seddighzadeh M, Brookes AJ, Alfredsson L, Klareskog L, Padyukov L, Fossum S: Association of arthritis with a gene complex encoding C-type lectin-like receptors. Arthritis Rheum 2007, 56:2620-2632.

73. Stastny P: Mixed lymphocyte cultures in rheumatoid arthritis. $J$ 
Clin Invest 1976, 57:1148-1157.

74. Rosloniec EF, Brand DD, Myers LK, Whittington KB, Gumanovskaya M, Zaller DM, Woods A, Altmann DM, Stuart JM, Kang AH: An HLA-DR1 transgene confers susceptibility to collagen-induced arthritis elicited with human type II collagen. $J$ Exp Med 1997, 185:1113-1122.

75. Wetsel RA, Fleischer DT, Haviland DL: Deficiency of the murine fifth complement component (C5). A 2-base pair gene deletion in a 5'-exon. J Biol Chem 1990, 265:2435-2440.

76. Okroj M, Heinegard D, Holmdahl R, Blom AM: Rheumatoid arthritis and the complement system. Ann Med 2007, 39:517530.

77. Moxley G, Ruddy S: Elevated plasma C3 anaphylatoxin levels in rheumatoid arthritis patients. Arthritis Rheum 1987, 30: 1097-1104.

78. Swaak AJ, Van Rooyen A, Planten O, Han H, Hattink O, Hack E: An analysis of the levels of complement components in the synovial fluid in rheumatic diseases. Clin Rheumatol 1987, 6: 350-357.

79. Gelderman KA, Hultqvist M, Holmberg J, Olofsson P, Holmdahl R: $T$ cell surface redox levels determine $T$ cell reactivity and arthritis susceptibility. Proc Natl Acad Sci U S A 2006, 103: $12831-12836$

80. Huang CK, Zhan L, Hannigan MO, Ai Y, Leto TL: P47(phox)-deficient NADPH oxidase defect in neutrophils of diabetic mouse strains, C57BL/6J-m db/db and db/+. J Leukoc Bio/ 2000, 67: 210-215.

81. Antonell A, de Luis O, Domingo-Roura X, Perez-Jurado LA: Evolutionary mechanisms shaping the genomic structure of the Williams-Beuren syndrome chromosomal region at human 7q11.23. Genome Res 2005, 15:1179-1188.

82. Olsson LM, Lindqvist AK, Kallberg $H$, Padyukov L, Burkhardt $H$, Alfredsson L, Klareskog L, Holmdahl R: A case-control study of rheumatoid arthritis identifies an associated SNP in the NCF4 gene supporting a role for the NOX-complex in autoimmunity. Arthritis Res Ther 2007, 9:R98.

83. Sakaguchi N, Takahashi T, Hata H, Nomura T, Tagami T, Yamazaki S, Sakihama T, Matsutani T, Negishi I, Nakatsuru S, Sakaguchi S: Altered thymic T-cell selection due to a mutation of the ZAP70 gene causes autoimmune arthritis in mice. Nature 2003, 426:454-460.

84. Chan AC, Iwashima M, Turck CW, Weiss A: ZAP-70: a 70 kd protein-tyrosine kinase that associates with the TCR zeta chain. Cell 1992, 71:649-662.

85. Yoshitomi H, Sakaguchi N, Kobayashi K, Brown GD, Tagami T, Sakihama T, Hirota K, Tanaka S, Nomura T, Miki I, Gordon S, Akira $S$, Nakamura T, Sakaguchi S: A role for fungal $\beta$-glucans and their receptor Dectin-1 in the induction of autoimmune arthritis in genetically susceptible mice. J Exp Med 2005, 201:949960.

86. Peters LL, Robledo RF, Bult CJ, Churchill GA, Paigen BJ, Svenson KL: The mouse as a model for human biology: a resource guide for complex trait analysis. Nat Rev Genet 2007, 8:58-69

87. Valdar W, Solberg LC, Gauguier D, Burnett S, Klenerman P, Cookson WO, Taylor MS, Rawlins JN, Mott R, Flint J: Genomewide genetic association of complex traits in heterogeneous stock mice. Nat Genet 2006, 38:879-887.

88. Valdar W, Solberg LC, Gauguier D, Cookson WO, Rawlins JN, Mott R, Flint J: Genetic and environmental effects on complex traits in mice. Genetics 2006, 174:959-984.

89. Demarest K, Koyner J, McCaughran J, Jr., Cipp L, Hitzemann R: Further characterization and high-resolution mapping of quantitative trait loci for ethanol-induced locomotor activity. Behav Genet 2001, 31:79-91.

90. Hitzemann B, Dains K, Kanes S, Hitzemann R: Further studies on the relationship between dopamine cell density and haloperidol-induced catalepsy. J Pharmacol Exp Ther 1994, 271:969976.

91. Talbot CJ, Nicod A, Cherny SS, Fulker DW, Collins AC, Flint J: High-resolution mapping of quantitative trait loci in outbred mice. Nat Genet 1999, 21:305-308.

92. Ewart-Toland A, Briassouli P, de Koning JP, Mao JH, Yuan J, Chan F, MacCarthy-Morrogh L, Ponder BA, Nagase H, Burn J, Ball S, Almeida $M$, Linardopoulos $S$, Balmain $A$ : Identification of Stk6/STK15 as a candidate low-penetrance tumor-susceptibility gene in mouse and human. Nat Genet 2003, 34:403-412.
93. Churchill GA, Airey DC, Allayee H, Angel JM, Attie AD, Beatty J, Beavis WD, Belknap JK, Bennett B, Berrettini W, Bleich A, Bogue M, Broman KW, Buck KJ, Buckler E, Burmeister M, Chesler EJ, Cheverud JM, Clapcote S, Cook MN, Cox RD, Crabbe JC, Crusio WE, Darvasi A, Deschepper CF, Doerge RW, Farber CR, Forejt J, Gaile D, Garlow SJ, et al:: The Collaborative Cross, a community resource for the genetic analysis of complex traits. Nat Genet 2004, 36:1133-1137.

94. Singer JB, Hill AE, Burrage LC, Olszens KR, Song J, Justice M, O'Brien WE, Conti DV, Witte JS, Lander ES, Nadeau JH: Genetic dissection of complex traits with chromosome substitution strains of mice. Science 2004, 304:445-448.

95. Gilad Y, Rifkin SA, Pritchard JK: Revealing the architecture of gene regulation: the promise of eQTL studies. Trends Genet 2008, 24:408-415.

96. Suntharalingam G, Perry MR, Ward S, Brett SJ, Castello-Cortes A, Brunner MD, Panoskaltsis N: Cytokine storm in a phase 1 trial of the anti-CD28 monoclonal antibody TGN1412. $N$ Engl J Med 2006, 355:1018-1028.

97. Padyukov L, Silva C, Stolt P, Alfredsson L, Klareskog L: A geneenvironment interaction between smoking and shared epitope genes in HLA-DR provides a high risk of seropositive rheumatoid arthritis. Arthritis Rheum 2004, 50:3085-3092. 